the covers; while the adult leaves of the third group withered and died in the course of a week. It was evident that the virus could and did move rapidly out of the younger leaves, and that the movement of food materials into them had little effect on the movement of virus out of them.

The conclusion that the movement of the virus takes place along the protoplasmic strands was confirmed by the observation that the embryo of the seeds of infected tobacco and tomato plants has been shown by the work of myself and others to be healthy and to contain no virus. This may be due to the irregular distribution of virus in the plant tissues and to the absence of direct protoplasmic connexion between the embryo and the parent plant.

The conclusion that the protoplasmic strands are not the paths of movement has also been supported just recently by another paper of Dr. Sheffield, in whioh she shows that the guard cells of the stomata of Solanum nodiflorum do not contain inclusion bodies, while the epidermal cells of this plant on infection with tobacco mosaic virus develop very characteristic inclusion bodies. It has been possible to demonstrate the existence of protoplasmic strands between the epidermal cells of this plant and their complete absence between the guard cells and the neighbouring epidermal cells.

The work on the nature of the virus has opened up some interesting fields for further study. Evidence is being accumulated which indicates that the virus is protein in nature and that it can develop only in living tissues, with which it is intimately connected. This conclusion is of special interest when it is remembered that tobacco virus No. 1 has been shown to exist in some sixty strains, most of which are known to be mutually antagonistic in the plant.

\title{
The Electrical Machinery Laboratory, Polytechnic, Regent Street, London
}

$\mathrm{T}$ 'HE newly-equipped Electrical Machinery Laboratory at the Polytechnic, Regent Street, was formally opened on December 10, by Sir E. Henry Pelham, permanent secretary to the Board of Education. The occasion was the jubilee commemoration of the School of Engineering, which first provided an organized engineering training in 1886 .

A feature of interest at the meeting was the presence of all three heads of the School, Mr. H. J. Spooner, the first head, who retired in 1922, Prof. A. R. Horme, professor of mechanical engineering at the Heriot-Watt College, Edinburgh, who retired in 1929, and Mr. Philip Kemp, the present head.

The Electrical Machinery Laboratory was first equipped in 1911 when the Polytechnic was re-built, and the machines and apparatus then installed did good service both before and after the Great War. It was realized, however, that if instruction had to be given on up-to-date lines, a thorough re-organization was necessary, and accordingly, plans were prepared for a complete new equipment. The London County Council was approached for financial assistance and a very generous grant was made, enabling the work to be begun in 1933 .

The main supply to the Laboratory, which has an area of 4,800 sq. ft., is obtained from the Borough of St. Marylebone three-phase mains at a pressure of 416 volts and a frequency of 50 cycles per second. This is fed to three $20 \mathrm{kva}$. three-phase transformers in order to step the voltage down to 100 volts, which is the value chosen for the operation of the experimental plant. These three transformers can be operated singly or in parallel, and are each provided with an auxiliary boosting transformer for the purpose of maintaining a constant voltage on the experimental circuits. This voltage is ultimately maintained at a constant value by means of an automatic voltage regulator.

Direct current supplies are obtained from two $15 \mathrm{kw}$. rotary converters, each with its own transformer. A 540 ampere-hour secondary battery is also available for D.c. work demanding a steady voltage. This battery is connected to the main D.c. bus bars, but has its own separate charging plant.
The experimental D.C. supply is taken to a special distribution board, before going away to the various experimental circuits.

The whole of the A.c. experimental supply is brought to a large plug board enabling single-phase or three-phase supply to be delivered to any of the experimental machines at will. If necessary, a particular circuit can be fed from one particular transformer, which can be isolated for the purpose. Signal lights are provided at various points to in. dicate live circuits.

Instead of using the transformers directly, alternative 100 volt A.c. supplies can be obtained from four $3 \mathrm{kva}$. three-phase alternators, these also being connected to the main plug board. Two of these alternators are separately driven by two threephase synchronous motors, a third by a three-phase commutator motor of the Schrage type, whilst the remaining alternator is driven by a D.c. motor.

A feature of the laboratory is the large-scale diagram printed on the wall, showing the whole of the experimental supply circuits.

The four motor-alternator sets mentioned above can be used for experimental purposes as well as for supplying other machines. The synchronous motors of the first two have their stators mounted on a rack and pinion, for the study of load conditions, and they are also each provided with a Joubert contact equipment for wave form investigations.

The D.c. testing plant consists of two 3-h.p. shunt motors, two 3-h.p. series motors and two $3 \mathrm{kw}$. motor-generator sets, the motors of which can be uncoupled at will.

Converting plant is represented by a $3 \mathrm{kw}$. threephase rotary converter and a $3 \mathrm{kw}$. six-phase rotary converter direct coupled to a 3-h.p. three-phase induction motor, so that the comkination can be run as a motor-converter if required. Both these sets are provided with Joubert contacts for wave form work.

Two mercury arc rectifiers are also installed, one being a $3 \mathrm{kw}$. single phase unit, whilst the other is a $3 \mathrm{kw}$. six-phase rectifier with grid control.

Alternating current motors are represented by two three-phase induction motors of 2 h.p. and 3 h.p. 
respectively, a 3-h.p. synchronous-induction motor, a 3-h.p. three-phase Schrage type commutator motor, and a 5-h.p. commutator motor which can be operated in a number of ways both single and three-phase.

A number of transformers are also available for experimental work of various types, including an equipment which can be used for three- to twophase transformation.

\section{Oscillatory Discharges in a Magnetic Field}

$\mathrm{H}^{\mathrm{I}}$ IGH-FREQUENCY oscillations produced in electrical discharges under the influence of a magnetic field have attracted considerable attention in recent years. In addition to their purely physical interest, they have proved of value to the engineer in the magnetron oscillator, a device which is quite closely related to the cyclotron, or proton accelerator, of Lawrence and Livingston. The secondary emission electron-multiplier of P. T. Farnsworth provides another example of a device in which oscillations can be produced by means of the co-operation of electric and magnetic fields; it differs from the magnetron in that the two fields are aligned instead of being approximately perpendicular.

Prof. T. V. Ionescu has recently described (C.R., $202,1160$ and $1842 ; 203,57 ; 1936)$ some interesting results relating to a somewhat similar type of discharge tube having a thermionic cathode, two ring-shaped electron-accelerating electrodes and a circular plate which could be given a positive or negative potential with respect to the cathode. A magnetic field was directed along the common axis of these electrodes. (Some results obtained with a similar kind of discharge tube were reported by Prof. K. Okabe recently in NaTuRe, 138,685 ; 1936). Measurement of the voltage-current characteristics of the plate at a gas pressure of the order of $10^{-7} \mathrm{~mm}$. (reported by Prof. Ionescu and Mr. C. Mihul) showed that an electron current could reach that electrode when its potential was below cathode potential (presumably indicating the presence of electronic oscillations) without any magnetic field. The effect of the magnetic field was to increase this current and apparently to split it up into components having different velocities.

In further experiments at a pressure rather less than $10^{-4} \mathrm{~mm}$., a luminous column appeared along the axis of the tube, between the second accelerating electrode and the plate, at a definite value of magnetic field strength. The form of this column varied with the electrode potentials, the cathode emission, and the magnetic field strength, but it apparently did not show the nodes and loops characteristic of ordinary magnetic focusing. The luminous column was found to persist for an appreciable time after the cathode emission was stopped. Electron currents up to several times the cathode emission were observed to flow away from the plate (secondary emission) and regions of negative resistance were obtained.

The tube appeared to be generating powerful highfrequency oscillations, but the available power does not seem to have been determined; the frequencies were of the order of $100-1,000 \mathrm{mc} . / \mathrm{s}$. In the last paper a theory of the oscillations is given which treats them as plasma electron oscillations modified by the magnetic field; two oscillation frequencies then arise in a way reminiscent of the Zeeman effect.

\section{Educational Topics and Events}

Cambridge.-The General Board has recommended that Dr. U. R. Evans continues as assistant director of research in metallurgy for five years from January 1 , 1937 , or for so long as the Iron and Steel Industrial Research Council continues its grant to the University for scientific research on corrosion, whichever period be the shorter.

It is recommended by the General Board that a readership in plant physiology be established as from October 1, 1936, and that G. E. Briggs (St. John's College) be appointed to that post.

LeEds.-Mr. Frank Parkinson, head of the firm of Crompton Parkinson, Ltd., and an old student of the University, has given $£ 200,000$ for the proposed main frontage to the University in connexion with the reconstruction scheme now proceeding. Earlier this year, Mr. Parkinson gave $£ 50,000$ for the establishment of a scholarship fund.

SHEFFIELD.-The following appointments have recently been made: J. L. A. Grout, to be honorary lecturer in radiological anatomy: G. Clark, to be junior assistant bacteriologist; W. A. Timperley, to be research fellow in the Department of Physiology.

DR. H. S. Ruse, lecturer in mathematics in the University of Edinburgh, has been appointed professor of mathematics at University College, Southampton, in succession to Prof. R. C. J. Howland, who died in August last.

The British Film Institute's third annual report tells of much useful work done and in progress : of answering inquiries from all parts of the Empire; supervising production of thirteen films illustrative of physical training; helping to produce thirteen films for use in the teaching of physics, ecology, and history; publishing a catalogue of British medical films ; preparing for the Child Welfare Committee of the League of Nations a report on entertainment films for children, and organizing a conference for discussing the same subject; publishing a new leaflet on non-theatrical apparatus and films for schools; and maintaining the publication of the quarterly Sight and Sound and monthly film bulletins. Nine local branches were in operation in England and Ireland, and a Scottish Film Council represents the Institute in Scotland. All this is good so far as it goes, but it must be admitted that the growth in membership has been disappointing. On June 30 there were 597 full and 1,700 associate (branch) members. If any substantial progress is to be made towards realizing the Institute's object "to influence public opinion to appreciate the value of films as entertainment and instruction", its efforts will need to have much more vigorous and widespread backing than they have hitherto received. No local education authority in Great Britain could deny the enormous importance of the objects for which the Institute was formed, and every one of them might well be a full member and help towards the formation of a local branch; but in fact the total number of education committees in Great Britain which have joined is 36 . 